\title{
PERANCANGAN DAN VALIDASI MODUL PENYUSUN SERIOUS GAME BERBASIS SEPEDA VIRTUAL UNTUK REHABILITASI PASCA STROKE
}

\author{
Muh. Fuad Al Haris ${ }^{1}$, Eka Mistiko Rini ${ }^{2}$ \\ ${ }^{1,2}$ Program Studi D3 Teknik Informatika, Politeknik Negeri Banyuwangi \\ Jalan Raya Jember KM. 13 Labanasem, Kabat, Banyuwangi 68461 \\ If harisepoliwangi.ac.id \\ ekamriniepoliwangi.ac.id
}

\begin{abstract}
In this research we present the modules of virtual reality augmented cycling (VRAC) system for people post stroke including mechatronic rehabilitation system and virtual environment. VRAC modules are designed as modular system to suit most stationary bicycles in virtual reality (VR) cycles without changing its parts. VRAC consists of novel hardware components embedded with sensors that are use to gain of a stationary exercise bicycle. VRAC modules include balancing pedals module, rpm (rotation per minute) counter module, safety driving module, handlebar module and acquisition data module. The handle system is a novel type of hand dynamometer, which measures applied physical force to control dynamic motion of the rider in the virtual environment. The data from sensing systems are measured by Arduino microcontroller as a acquisition data module and sent its results to virtual environment processed by computer. The prototype of the system was successful in demonstrating that a modular mechatronic kit can monitor and record kinetic, kinematic and physiologic parameters of riders.
\end{abstract}

Keywords - serious game, VRAC modules, balance, rpm, handlebar, safety driving, virtual environment

\section{Pendahuluan}

Kombinasi antara lingkungan virtual dengan robotik dan manusia telah menghasilkan efektifitas kerja yang kompleks dan meningkatkan keselamatan dalam beraktivitas kerja [1]. Penggunaan sepeda yang dipadukan dengan aplikasi permainan telah berhasil meningkatkan intensitas latihan dalam meningkatkan kebugaram [2, 3]. Tetapi, di pasaran masih belum ditemukan perangkat virtual reality yang ditambahkan pada sepeda statis untuk rehabilitasi pasca Stroke, dimana perangkat yang ada lebih banyak di desain untuk latihan normal dan sistem yang dikembangkan belum modular sehingga tidak bisa diterapkan pada jenis sepeda statis lainnya.Untuk mengatasi permasalahan ini, dalam penelitian ini telah dikembangan perangkat serious game berbasis virtual reality (VR) yang ditambahkan pada sepeda statis (virtual reality augmented cycling/VRAC) bagi rehabilitasi penderita pasca Stroke. Pengembangan perangkat VRAC didukung oleh modul-modul perangkat keras yang dilengkapi dengan sensor-sensor dan lingkungan virtual yang dapat dipasangkan pada berbagai sepeda statis.

Untuk mengevaluasi masalah gangguan motorik otot pada ekstremitas bawah maka pada perangkat VRAC ditambahkan modul pedal yang dilengkapi perangkat keras dan sensor untuk mengetahui ketidakseimbangan tekanan kaki yang mempengaruhi gaya berjalan [4, 5]. Denyut jantung digunakan untuk mengontrol keamanan selama latihan menggunakan sepeda statik [6, 7]. Untuk mengatasi alat kemudi pada sepeda statik tanpa harus merubah fungsi atau bentuk sepeda statik maka dalam penelitian ini dikembangkan desain alat kemudi yang tidak hanya berfungsi sebagai kontrol stir tetapi juga menguatkan otot 
pada ekstremitas atas. Sedangkan desain lingkungan virtual yang dibuat memiliki perbedaan spasial dan waktu tunda yang kecil seperti dijelaskan lebih detil dalam [8].

\section{SiSTEM PERANGKAT VRAC}

Desain lengkap dari modul penyusun sistem perangkat VRAC ditunjukkan Gambar 1. Penggunaan komponen pada sistem dirancang secara modular sehingga dapat digunakan pada semua sepeda statis untuk mengukur keseimbangan dalam berjalan, gaya berjalan, keamanan latihan dan gerak motorik otot.

Akusisi data dari sensor load-cell (Gambar 1A), sensor hall-effect (Gambar 1-B), sensor Flex (Gambar 1-C) dan sensor denyut jantung (Gambar 1-D) dilakukan oleh mikrokontroler Arduino yang diolah dan dikirimkan ke PC melalui komunikasi serial seperti ditunjukkan Gambar 1-F. Hasil pengolahan data dari sensor akan diproses oleh pengolah VR dan divisualisasikan pada layar penampil (Gambar 1-G), sedangkan keamanan latihan bagi penderita pasca Stroke dapat dimonitor pada mesin EEG seperti ditunjukkan Gambar 1-H.

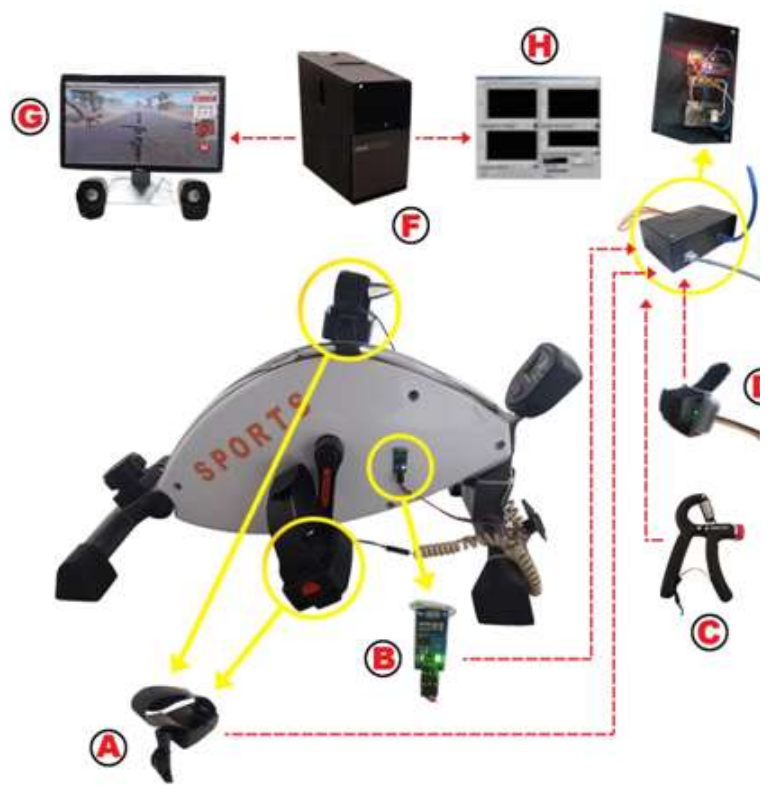

Gambar 2. Sistem perangkat VRAC; A: modul keseimbangan; B: modul putaran pedal;C: modul alat kemudi; D: modul denyut jantung; E: modul akusisi data; F: pengolah VR; G: layar penampil; H: monitor EEG

\section{Modul Pedal}

Modul pedal yang digunakan dalam VRAC ini bersifat umum dimana sensor load cell dirancang agar dapat ditempatkan di atas permukaan pijakan kaki dari pedal sepeda statis yang ditunjukkan Gambar 2(a). Nilai tekanan kaki dari sensor load cell ini dibaca menggunakan mikrokontroler Arduino seperti ditunjukkan Gambar 2(b).

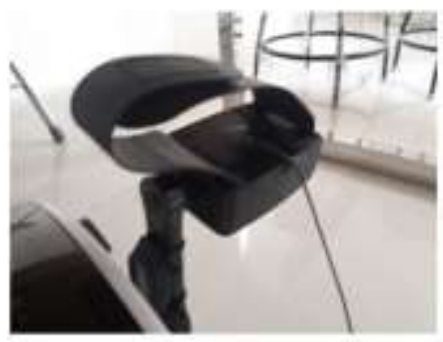

(a)

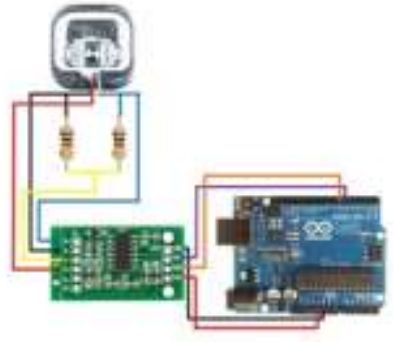

(b)
Gambar 2. Desain pedal VRAC: (a) penempatan sensor load cell; (b) diagram skematik

Dari Gambar 2(b), konfigurasi pin dari sensor load cell $50 \mathrm{Kg}$ tipe MLC902 terdiri atas kabel merah adalah input tegangan sensor, kabel hitam adalah input ground sensor, kabel biru adalah output positif sensor dan kabel kuning adalah output ground sensor. Keluaran dari sensor load cell dikuatkan dengan rangkaian amplifier jenis HX711 dengab 24 bit ADC sebelum dihubungkan dengan mikrokontroler Arduino.

\section{MODUl JUMLAH PUTARAN KAYUHAN}

Akuisisi data putaran kayuhan pedal (jumlah rotasi per menit) dihitung menggunakan sensor magnetik seperti ditujukkan Gambar 3. Modul sensor ini menggunakan reed switch sebagai sensor probe (elemen pendeteksi) untuk memindai keberadaan medan magnet. Module sensor ini juga dilengkapi dengan trimpot dan IC pembanding tegangan (voltage comparator) LM393 sehingga tingkat sensitivitas dapat diatur terhadap kekuatan paparan medan magnet. Keluaran dari modul sensor ini adalah sinyal digital TTL (bernilai HIGH saat kekuatan medan magnet yang terdeteksi melebihi ambang batas yang diatur oleh potensiometer). Kalibrasi dilakukan menggunakan tachometer. 


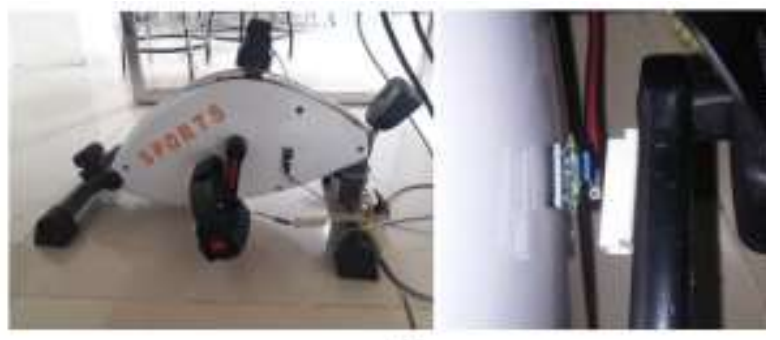

(a)

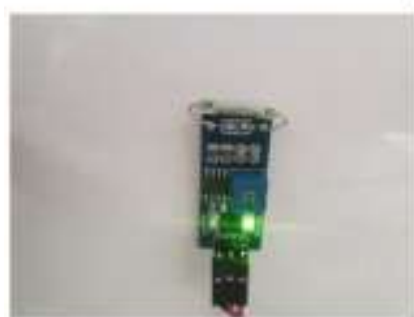

(b)

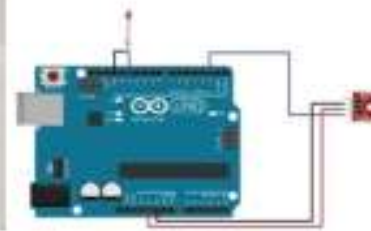

(c)
Gambar 3. Pengukuran jumlah putaran: (a) posisi penempatan reed switch pada lengan ayun sepeda; (b) modul magnetik reed switch; (c) diagram skematik

\section{Modul Pengukuran Denyut Jantung}

Akuisisi denyut jantung menggunakan sensor heart-rate yang dipasang di lengan tangan untuk mengontrol kecepatan ayunan pedal pada virtual trainer dan untuk keamanan latihan seperti ditunjukkan Gambar 4.

\section{MODUl Alat KeMUdi}

Alat kemudi yang desainnya diperlihatkan Gambar 5. dipasang di bagian horizontal di pegangan tangan bagian kiri dan kanan sepeda statis menggunakan klem dan dikencangkan dengan baut. Alat kemudi dipasang secara vertikal dan kemiringan posisinya dapat disesuaikan dengan jangkauan tangan pengguna. Bagian-bagian alat kemudi dilengkapi dengan tuas plastik untuk genggaman tangan yang berfungsi untuk menarik ulur pegas yang terpasang di bagian atas alat kemudi. Kekakuan tarikan pegas (beban pegas dalam satuan $\mathrm{kg}$ ) dapat diatur menggunakan tombol putar dengan kapasitas mulai $5-25 \mathrm{~kg}$. Alat kemudi ini dilengkapi engsel untuk menggerakkan naik turunnya pegas. Sensor Flex dipasang di antara gengaman hand dynamometer menggunakan klem seperti ditunjukkan Gambar 5. Sensor Flex ini akan mengubah tekanan tangan pada tuas yang menghasilkan regangan pada pegas menjadi nilai lengkungan pada sensor Flex dimana luarannya berupa tegangan $0-5 \mathrm{~V}$ yang mewakili derajat lekukan. Sensor Flex memiliki dua kabel luaran dimana satu kabel dihubungkan dengan $\mathrm{Vcc}+5 \mathrm{~V}$ dan satu kabel dihubungkan Gnd. Luaran kabel $\mathrm{Vcc}+5 \mathrm{~V}$ dihubungkan dengan resistor $10 \mathrm{k} \Omega$ yang dihubungan secara seri dengan pin data dan Vcc dari unit mikrokontroler, sedangkan luaran kabel Gnd dihubungan dengan pin Gnd dari unit mikrokontroler. Data dari sensor Flex diubah oleh ADC pada unit mikrokontroler menjadi data digital dan menghasilkan nilai lekukan (dalam derajat) dari sensor Flex. Luaran mikrokontroler berupa status belokan (kiri, kanan, lurus) dan derajat belokan diteruskan ke CPU pengolah virtual reality bersepeda melalui komunikasi serial untuk mengontrol arah belokan sepeda virtual pada lingkungan virtual yang hasilnya ditampilkan pada layar monitor.

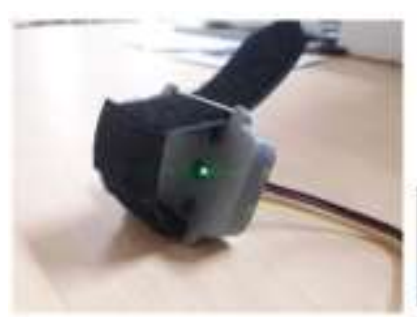

(a)

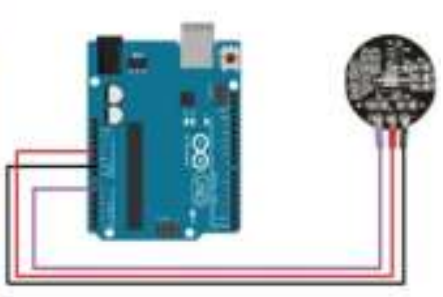

(b)
Gambar 4. Pengukuran denyut jantung: (a) sensor heart rate; (b) diagram skematik

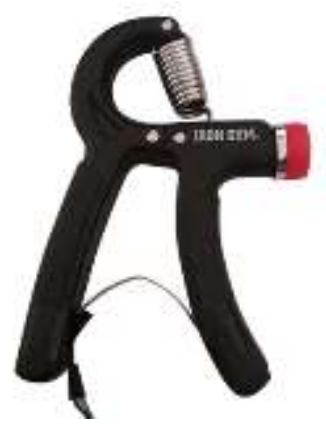

Gambar 5. Alat kemudi sepeda statis menggunakan sensor Flex dan hand dynamometer

\section{LINGKUNGAN VIRTUAL}

Lingkungan Virtual (Virtual EnvironmentVE) dibuat menggunakan Unity $5.4^{\mathrm{TM}}$ dengan bahasa pemrograman C\#. Obyek dalam VE dirancang untuk melatih gerak motorik ekstremitas bawah dan atas seperti ditunjukkan Gambar 6. Desain VE untuk latihan ekstremitas bawah dibagi menjadi tiga kondisi, yaitu (1) kondisi pertama ketika tekanan ayunan pedal tidak seimbang maka obyek pengguna dalam VE akan menunjukkan kemiringan ke sisi kiri atau sisi kanan ketika mengendarai sepeda seperti ditunjukkan Gambar 5.8(a) dan (b); (2) kondisi kedua adalah jarak tempuh sepeda di VE dihitung berdasarkan rumus $(2 \pi *$ radius 
roda) * RPM; (3) dan kondisi ketiga adanya pelatih yang bersepeda di depan pengguna. Kecepatan rata-rata sepeda pelatih ditentukan dari maksimum kecepatan pengguna ketika melakukan pemanasan awal sebelum latihan dimulai. Pengguna harus menjaga jarak dengan pelatih dimana pengguna tidak boleh terlalu cepat sampai melebihi pelatih atau terlalu lambat dalam mengayuh sepeda. Ketika pengguna bersepeda terlalu jauh dari pelatih maka secara otomatis pelatih akan menurunkan kecepatannya. Sedangkan untuk melatih ekstremitas atas digunakan pengontrolan alat kemudi melalui gerakan motorik otot lengan.

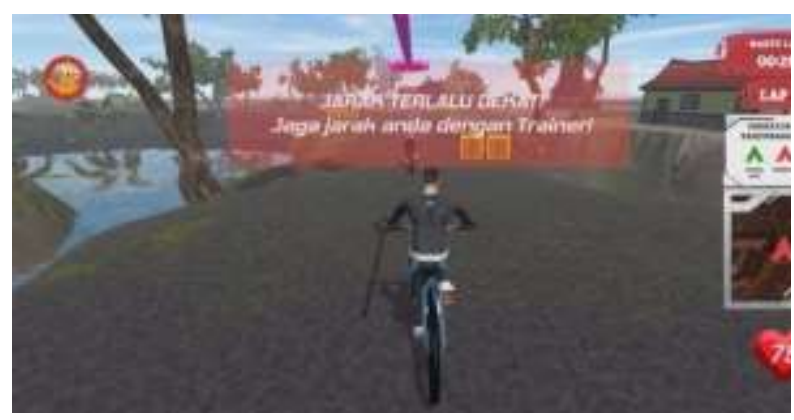

Gambar 6. Desain lingkungan virtual

\section{PenguJian dan VALIDASI MODUl VRACK}

Pengujian dan validasi perangkat VRAC digunakan untuk mengetahui kinerja dari modul-modul VRAC yang melibatkan dua orang sehat ( 2 orang; rata-rata umur 22.5 ; 21 24 tahun).

\section{Data Denyut Jantung}

Akuisisi data denyut jantung ditunjukkan dari garis biru pada Gambar 7. Untuk menghilangkan gangguan pada data denyut jantung dilakukan linear spline interpolation (ditunjukkan garis merah pada Gambar 7), kemudian dilakukan filter menggunakanfilter low pass Butterworth orde 4 dengan frekuensi cut-off $0.5 \mathrm{~Hz}$ (ditunjukkan garis hijau pada Gambar 7).

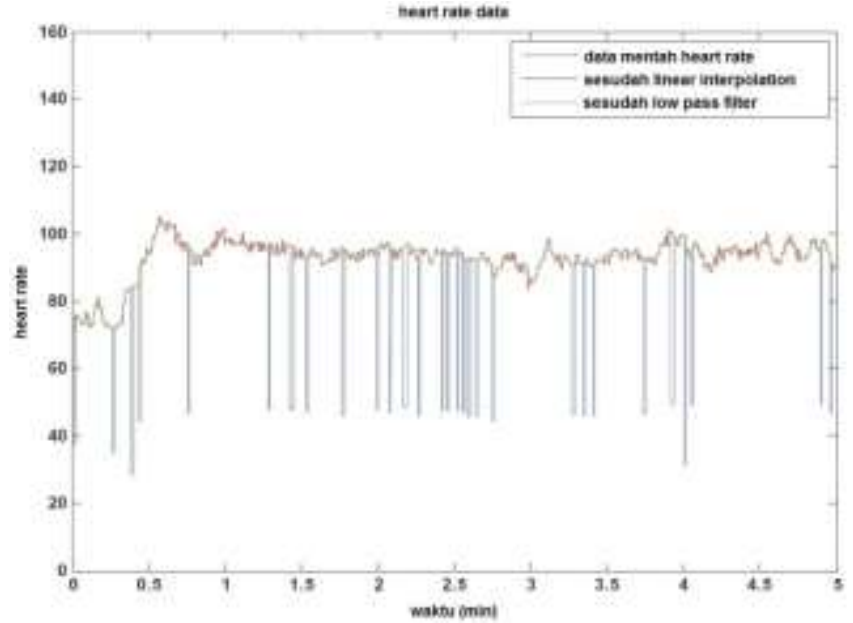

Gambar 7. Pengambilan data denyut jantung 5 menit pertama waktu latihan VRAC

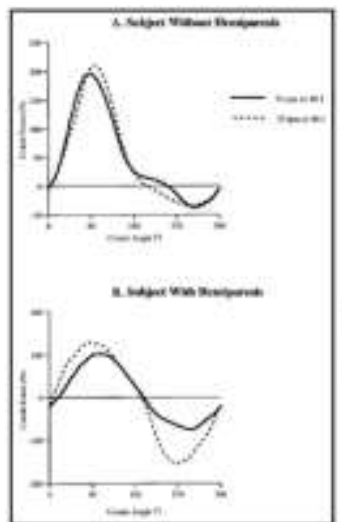

(a)

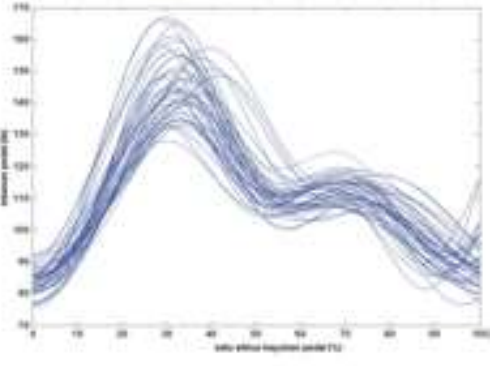

(b)
Gambar 8. Karakteristik tekanan pedal VRAC dalam satu siklus: (a) pembanding [9]; (b) luaran tekanan pedal dari sistem yang dibuat

\section{Data Tekanan Pedal}

Gambar 8 menunjukkan karakteristik tekanan pedal dalam satu putaran untuk orang sehat. Data mentah tekanan pedal dilakukan filter menggunakan low pass Butterworth orde 4 dengan frekuensi cut-off $5 \mathrm{~Hz}$. Puncak grafik menunjukkan maksimum gaya tekananan pedal yang terjadi selama kondisi menurun sekitar 30$40 \%$ dari satu siklus mengayuh VR-Cycling. Gambar 8(a) menunjukkan karakteristik kayuhan pedal pada orang sehat dan orang dengan stroke sebagai bahan pembanding modul tekanan pedal yang dibuat yang diuji pada dua kecepatan yang berbeda dimana pada kecepatan yang berbeda, tekanan pedal pada orang sehat dalam satu putaran mencapai puncak antara $30-40 \%$ dan memiliki lengkungan grafik yang sama. Tetapi, tekanan pedal dalam satu putaran pada orang dengan stroke menghasilkan grafik yang berbeda dimana semakin tinggi kecepatan ayuhan pedal 
maka terjadi penurunan kekuatan otot yang lebih besar. Gambar 8(b) menunjukkan kesesuaian karakteristik luaran modul tekanan pedal pada sistem yang dibuat yang dibandingkan dengan [9].

\section{Data Tekanan Alat Kemudi}

Sedangkan dari hasil luaran tekanan pegas pada alat kemudi yang ditunjukkan Gambar 9. menunjukkan nilai yang dikeluarkan oleh sensor Flex semakin membesar ketika tekanan pada hand dynamometer semakin besar pada bagian kiri dan kanan.

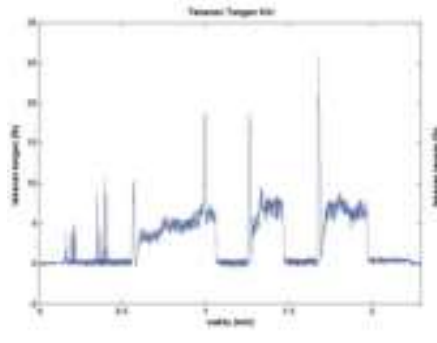

(a)

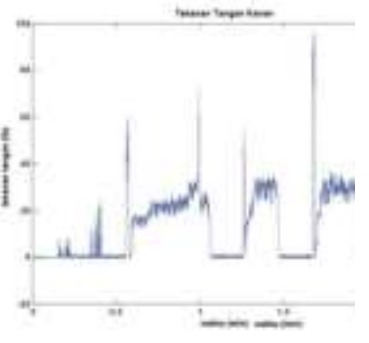

(b)
Gambar 9. Karakteristik tekanan pegas pada alat kemudi VRAC dimana (a) tekanan pegas bagian kiri; (b) tekanan pegas bagian kanan

\section{KESIMPULAN}

Dari hasil penelitian yang telah dilakukan dapat disimpulkan bahwa sistem mekatronika perangkat VRAC yang meliputi keseimbangan tekanan pedal, denyut jantung, tekanan pegas pada alat kemudi dan dan jumlah putaran kayuhan pedal dapat berjalan dengan baik sesuai karakteristik pengguna VRAC dimana modul-modul mekatronika VRAC ini dapat terintegrasi dengan baik dengan lingkungan virtual simulator VRAC.

\section{DAFTAR PUSTAKa}

[1] Oyekan, J. O., Hutabarat, W., Tiwari, A., Grech, R., Aung, M. H., Mariani, M. P., ... \& Dupuis, C. (2019). The effectiveness of virtual environments in developing collaborative strategies between industrial robots and humans. Robotics and ComputerIntegrated Manufacturing, 55, 41-54.

[2] Interactive Fitness Holdings LLC. (2018). The Expresso family of interactive bikes. Diakses dari www.expressofitness.com/

[3] Electronic Sports. (2018). Dogfight. Diakses dari http://electronicsports.com/.

[4] Schaffert, N., Godbout, A., Schlueter, S., \& Mattes, K. (2017). Towards an application of interactive sonification for the forces applied on the pedals during cycling on the Wattbike ergometer. Displays, 50, 4148.

[5] Rogers, L. M., Brown, D. A., \& Gruben, K. G. (2004). Foot force direction control during leg pushes against fixed and moving pedals in persons post-stroke. Gait \& posture, 19(1), 58-68.

[6] Jain, S., Gourab, K., Schindler-Ivens, S., \& Schmit, B. D. (2013). EEG during pedaling: evidence for cortical control of locomotor tasks. Clinical Neurophysiology, 124(2), 379-390.

[7] Stach, T., Graham, T. C., Yim, J., \& Rhodes, R. E. (2009, May). Heart rate control of exercise video games. In Proceedings of Graphics interface 2009 (pp. 125-132). Canadian Information Processing Society.

[8] Lesmana, I. P. D., Widiawan, B., Hartadi, D. R., \& Al Haris, M. F. (2018). Pengembangan Terapi Cermin Pada Latihan Bersepeda Berbasis Virtual Reality Untuk Meningkatkan Gerak Motorik Ekstremitas Atas Pasca Stroke. Jurnal Teknologi Informasi dan Ilmu Komputer, 5(4), 503-510.

[9] Brown, D. A., \& Kautz, S. A. (1999). Speeddependent reductions of force output in people with poststroke hemiparesis. Physical therapy, 79(10), 919930. 
Desain dan Implementasi Data warehouse Untuk Prediksi Penjualan 